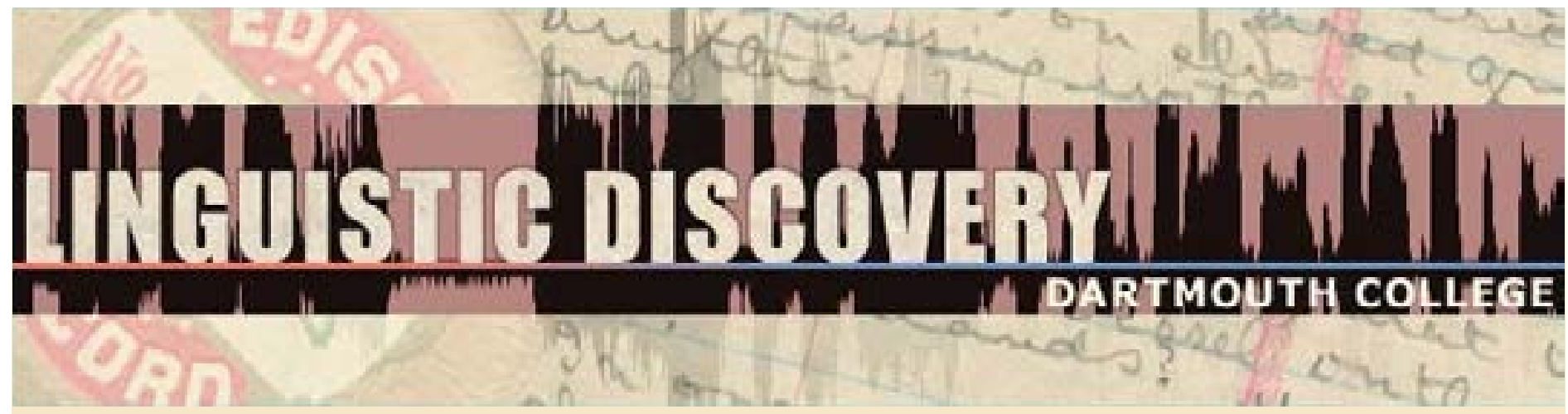

\begin{tabular}{|l|}
\hline Volume 11 \\
Issue 1 \\
2013 \\
\hline
\end{tabular}

\title{
Object Markers in Ikalanga
}

Rose Letsholo

University of Botswana

doi: $10.1349 / P S 1.1537-0852 . A .436$

url: http://journals.dartmouth.edu/cgi-bin/WebObjects/ Journals.woa/1/xmlpage/1/article/436

\section{Linguistic Discovery}

Published by the Dartmouth College Library Copyright to this article is held by the authors. ISSN 1537-0852 linguistic-discovery.dartmouth.edu 


\section{Object Markers in Ikalanga \\ Rose Letsholo \\ University of Botswana}

There is an on-going debate amongst linguists regarding the status of the object marker (OM). Some scholars argue that OMs are agreement morphology (Baker 2010, Riedel 2009) while others argue that OMs are pronominal and not agreement morphology (Nevins 2010, Kramer, under review, Labelle 2007, Demuth \& Johnson 1990, Mchombo 2002). The purpose of this paper is to contribute to this debate using data from Ikalanga to support the view that OMs are pronominal clitics. I discuss evidence in favor of the agreement analysis as well as that in favor of the pronominal analysis. OMs in Ikalanga behave like agreement morphology in that they attach only to the verbal stem, only one OM occurs in a clause, and they share grammatical features (person, gender and number) with the lexical NP with which they co-refer. However, there are many ways in which OMs behave like pronominals. For example, OMs do not vary in form according to the mood of a sentence or negation while subject markers, which I analyze as agreement morphemes do. They are not obligatory in Ikalanga sentences while subject markers are. OMs are not subject to locality constraints while agreement is. They can be bound by the subject (backward pronominalization), something unexpected of agreement and there is ample evidence to show that the lexical NP with which the OM co-refers is an adjunct, a fact which has been used in the literature to argue that the OM is pronominal in such a set up. The evidence in favor of the pronominal analysis however, is more compelling and therefore I conclude that OMs are pronominal clitics and not agreement morphology.

\section{Introduction}

A vast amount of literature exists on the topic of object markers in languages of the world and in Bantu languages in particular. Most papers that have been written on this subject investigate the status of the OM in these languages e.g. Kramer (under review), Baker (2011), Hyman \& Duranti (1982), Bresnan and Mchombo (1987), Demuth \& Johnson (1990) Siedl \& Dimitriadis 1997, Keach (1995) while others investigate the general characteristics of OMs in Bantu e.g. Marten and Kula (ms.), Riedel (2009) with the hope of finding some generalizations that cut across this language group. While there are some interesting similarities in OMs across Bantu languages, it is nevertheless a fact that OMs behave differently in different Bantu languages. For example, in some languages OM is sometimes obligatory with lexical object NPs - these languages include Swahili, Chaga and Saamba (Riedel 2009). In such languages, OM has been analyzed as an agreement marker. In other languages, e.g Chichewa, Zulu, and Sesotho, OM co-occurs only with dislocated object NPs. In these languages, OM has been analyzed as an incorporated pronoun (e.g. Bresnan \& Mchombo 1987, Labelle 2007, Demuth \& Johnson 1990, Mchombo 2002, Siedl \& Dimitriadis 1997 Hyman \& Duranti 1982). Because of its inconsistent behavior, it has been difficult for scholars investigating this topic to make a generalization regarding the syntactic status of the OM in terms of whether it is an agreement marker or some kind of pronoun. In the quest for uniformity of analysis of this phenomenon, Riedel (2009) proposes that all OMs in Bantu languages are agreement markers. I will argue against this view in this paper using data from Ikalanga, one of the minority languages spoken in Botswana, to support my arguments. This paper aims at making a contribution to this debate. The main question that this paper investigates therefore is 'What is the status of the OM in Ikalanga?' 
The rest of this paper is organized as follows: Section 2 provides background information on the Ikalanga language while section 3 discusses the theoretical framework adopted in this paper. Section 4 discusses evidence in favor of the agreement analysis in Ikalanga while section 5 presents evidence in favor of the pronominal analysis. Section 6 provides the conclusion.

\section{Background}

\subsection{Ikalanga word order facts}

Ikalanga (S16) is a Bantu language spoken in parts of Botswana and parts of Zimbabwe (it is one of the minority languages in both countries). It is basically an SVO language (example 1a) although arguments can occur in a position other than their canonical position as illustrated in (1b).

(1a) Néó wá-ka-bíká nya:ma ${ }^{1}$.

$\mathrm{NeO}_{1 \mathrm{a}} \quad \mathrm{SA}_{1}$-PST-cook meat 9

'Neo cooked/is cooking meat'

(1b) Wá-ka-bíká nya:ma, Neo.

$\mathrm{SA}_{1}$-PST-cook meat $9 \mathrm{Neo}_{1 \mathrm{a}}$

'She cooked the meat, Neo.' (VOS)

Ikalanga is a pro-drop language. Consider example (2).

(2) Wá-ka-bóná mbísá:na.

SA $_{1}$-PST-see boy

'She/He saw a boy'.

The data in (2) shows that (2) can be interpreted to mean 'He/she saw a boy'. Without going into any specifics of determining the status of the SA, in this paper, I will assume that the SA is an agreement morpheme which agrees with a null subject pro (see Letsholo 2004 for further discussion of this phenomenon). Before any further discussion of the OM in Ikalanga, I first describe verbal extensions found in the language and then provide the theoretical assumptions that will be used to analyze the data in this paper in section 3.

\subsection{The verb in Ikalanga}

The verb in Ikalanga comprises of the verb root (VR) which hosts (suffixal) extensions such as those shown in example (3):

\footnotetext{
${ }^{1}$ Abbreviations: APPL. = applicative, COND. = conditional, FUT. $=$ future tense, FV = final vowel, NEG. $=$ negation, $\mathrm{OM}=$ object marker, $\mathrm{PRS}=$ present tense, $\mathrm{PST}=$ past tense, $\mathrm{SA} / \mathrm{SM}=$ subject agreement marker, $\mathrm{SBJV}=$ subjunctive, $\mathrm{STAT}=$ stative, $\mathrm{VR}=$ verb root
} 


$\begin{array}{llll}\text { (3a) } & \text { applicative } & \text { bumb-il-a } & \text { (build for) } \\ \text { (3b) } & \text { causative } & \text { bumb-is-a } & \text { (cause to build) } \\ \text { (3c) } & \text { reciprocal } & \text { bumb-an-a } & \text { (build each other) } \\ \text { (3d) } & \text { passive } & \text { bumb-iw-a } & \text { (to be built) } \\ \text { (3e) } & (a+b+c) & \text { bumb-is-an-il-a } & \text { (cause to build for each other) }\end{array}$

In addition, the verb in Ikalanga also has prefixal elements which encode information about agreement with the subject, tense/aspect, object marker, negation and modality. These are illustrated in the examples in (4) below ${ }^{2}$. The different morpheme combinations that are affixed to the verb are indicated in brackets in examples (4a-d) below.

(4a) Néó wá- ka- bón-á mbísá:na.

$\mathrm{NeO}_{1 \mathrm{a}} \quad \mathrm{SA}_{1}$ - PST see-FV boy

'Neo saw a boy'. (SA+Tense + VR+ FV)

(4b) Néó wá- ka-m -bó:n-a mbísána.

$\mathrm{Neo}_{1 \mathrm{a}} \quad \mathrm{SA}_{1} \mathrm{PST}_{-\mathrm{OM}}$ - see-FV boy

'Neo saw him, the boy'. $\quad$ (SA+Tense + OM+ VR+ FV)

(4c) Néó a-á- zo-m- bó:n-a mbísána.

$\mathrm{Neo}_{1 \mathrm{a}} \quad$ NEG.-SM 1 -PST-OM - -see-FV boy

'Neo did not see him, the boy'. $\quad$ (NEG.+SA+Tense+OM+VR+FV)

(4d) Néó a-é- zh-á, Nchídzí ú-noo m -bó:n-a.

$\mathrm{Neo}_{1 \mathrm{a}} \quad \mathrm{COND}$.-SA ${ }_{1}$-come -FV Nchidzi ${ }_{1} \quad \mathrm{SA}_{1}$-PRS.-OM $\mathrm{OM}_{1}$-see-FV

'If Neo comes, Nchidzi will see her/him'. $\quad$ (Cond+SM+VR+FV)

\section{Theoretical Assumptions}

Central to the analysis adopted in this paper is the notion of agree proposed in Chomsky (2000, 2001). Agree is a relation established in the syntax between a functional head and a DP. In this theory, a functional head that has un-interpretable features probes within its c-command domain for a DP (goal) which has matching features. If such a DP with matching un-interpretable features is found, then such a DP enters into an Agree relation with the probe and checks its un-interpretable features. Agreement is governed by locality restrictions, for example there cannot be an intervening NP between the functional head which is the probe and the goal, that is the NP with matching features. That said, Chomsky (2001) raises the possibility that agreement can hold in non-local configurations. However, in this paper I adopt the conception of agreement where it is a local configuration because to the best of my knowledge agreement relations in Ikalanga are strictly local. Further, I assume that $v \mathrm{P}$ has EPP features which necessitate object shift but that in Ikalanga object shift is covert in non-specific DPs and overt for specific DPs. In addition, I assume that adjunction can occur to the right or to the left of the tree. For example, I assume that right adjunction is responsible for the derivation of English sentences such as 'I saw a picture yesterday

${ }^{2}$ Notice that the vowel in the verb 'bona' in (4a) is short while the same vowel in (4b\&c) is long. The reasons for this distinction will be discussed in section 5.2.3.1. 
of the man I met at the store'. In addition, I appeal to theta theory where relevant to explain phenomena in Ikalanga. Before putting forth my proposed analysis of object markers in Ikalanga, I briefly discuss recent analyses of similar phenomena in other languages, pointing out why these anslyses cannot be adopted for Ikalanga.

Nevins (2010) analyzes object markers as pronominal clitics which form part of a big DP structure. In this analysis, the clitic starts off adjoined to the doubled DP before it moves to spec $v \mathrm{P}$ where it undergoes m-merger with $v$ per Matushansky (2006). Clitic movement to spec $v \mathrm{P}$ is regarded as object shift triggered by an EPP feature on $v$ and licensed by an agree relation. This structure is shown in (5) below:

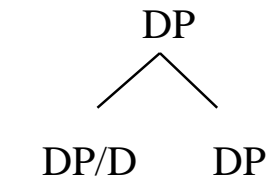

after DP/D movement and m-merger

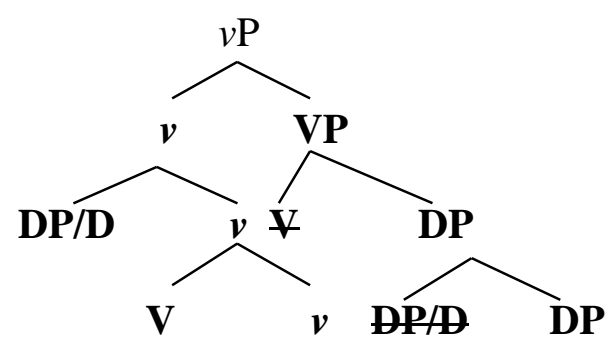

A modified version of this analysis is proposed in Kramer (under review) ${ }^{3}$ which she refers to as the copy analysis of object markers. This analysis is similar to the Nevins analysis discussed above in every respect with the exception that under this analysis there is no separate DP/D clitic adjoined to the doubled DP. In this analysis, $v$ agrees with the DP which then moves to spec $v$ P. The DP then m-merges with $v$ and the clitic adjoins to $v$. According to Kramer, both copies of the doubled DP are pronounced (Kramer, under review: 26).

While both of these analyses are interesting and nicely capture the relationship between the $\mathrm{OM}$ and the lexical NP with which it co-refers, neither of them can be adopted for Ikalanga (without modification) for different reasons. Both Nevins adjunction analysis and Kramer's copy analysis could potentially work for Ikalanga (with modifications that call for stipulations) putting aside the adjunction analysis shortcomings which are clearly articulated in Kramer. However, there are two main problems that both of these analyses seem to pose with regards to the Ikalanga data. The first one is that in both of these analyses, it is not clear from the authors' discussions whether the lexical object NP that co-occurs with the OM is an adjunct in the languages discussed and the structures proposed in both analyses do not suggest that this is the case. In Ikalanga, as I will argue below, the lexical object NP that co-occurs with the OM is not part of the VP. Secondly, the structure proposed in Kramer produces the wrong word order for Ikalanga. Thus, because of these shortcomings, I cannot adopt their big DP analysis without any modification.

\footnotetext{
${ }^{3}$ The only Kramer article referenced in this paper is the one under review and henceforth I reference it just as 'Kramer' in the text.
} 
There are two possible analyses that could work for Ikalanga and I discuss each of them below. The first proposal is that the OM is a clitic which occupies the D head of DP and that the lexical DP orginates as a complement of $\mathrm{D}$ but is then adjoined to some functional category on the right as shown in (6) below. The adjunction analysis proposed below is consistent with analyses proposed for English sentences such as 'I thought for a very long time that somebody would come' where the clause 'that somebody would come is extraposed to the right (Collins, p.c.).

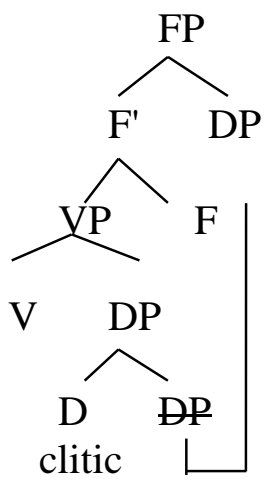

This analysis has the advantage that it captures the relationship between the clitic and lexical NP with which it co-refers. The problem with this structure is that it requires that we stipulate the existence of some functional projection FP, to which the lexical NP can adjoin. Secondly, one is hard-pressed to justify the reason for the movement of the adjoined DP since movement in minimalism is motivated by feature checking. In addition, this analysis might be a problem if one adopts Kayne (1994) since this structure violates antisymmetry.

Due to the shortcomings discussed above, I propose an analysis in which the lexical DP which co-refers with the OM is base generated to the right in the tree diagram. The analysis I adopt in this paper is not widely used in the literature. That notwithstanding, I find that this analysis best accounts for the Ikalanga data as well as the data found in other Bantu languages such as Chichewa and Zulu. First and foremost, consonant with others who have investigated OMs (Bresnan \& Mchombo (1987), Nevins (2010), Kramer (under review and many others) I analyze Ikalanga OMs as pronominal clitics and not agreement markers. Following the big DP analysis, I propose that in sentences in which the OM occurs, the verb takes a null DP complement with the pronominal clitic DP/D in the specifier of this DP. Unlike in the big DP analysis, I assume that the lexical object DP is adjoined to VP and not itself a complement of V. Secondly, I assume that the complement DP of $\mathrm{V}$ containing the OM undergoes object shift to spec $v \mathrm{P}$ to check the EPP feature of $v$ and that $\mathrm{OM}$ undergoes $\mathrm{m}$-merger with the verb at PF. The structure that results is shown in (7) below. 


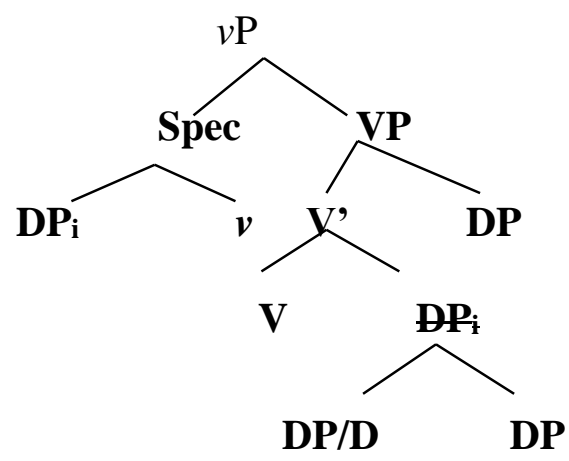

$\varnothing$

This analysis has the disadvantage that it does not capture the relationship between the lexical NP with which the OM co-refers since this NP is base generated as an adjunct. However, the analysis has the advantage that it captures the fact that the lexical NP is an adjunct and is outside VP as the evidence presented below indicates. The analysis also has the advantage that it captures the specificity interpretation of sentences in which the OM occurs. I now turn to the debate regarding whether the $\mathrm{OM}$ is agreement or a pronominal clitic in Ikalanga. I first present arguments which suggest that the $\mathrm{OM}$ in Ikalanga is agreement and then present arguments which favor the pronominal clitic analysis.

\section{Object Markers as Agreement}

While the position I take in this paper is that object markers are pronominal clitics and not agreement morphology, there is nonetheless some evidence to suggest that OMs might be agreement morphology in Ikalanga. Such evidence include the position of the OM in relation to the verbal stem, the number of OMs per clause and the fact that OMs share phi features with the lexical NPS with which they co-refer.

\subsection{Position in relation to verbal stem}

The OM in Ikalanga attaches only to the verbal stem (ex 8a) and not to any other element such as auxiliaries or other hosts as do clitics in Indo-European languages such as Romanian (9). Attaching an OM to say, an auxiliary verb in Ikalanga results in ungrammaticality as evident from the ungrammaticality of (8b).

(8a) Nchídzí ú- nga- m-bó:n-a

Nchidzi $i_{1 a} \quad \mathrm{SA}_{1}-\mathrm{OM}_{1}$-Aux- -see-FV

'Nchidzi can see him/her. (OM = 3rd person singular, class 1)

*Nchídzí ú-m-nga bó:n-a

Nchidzi $_{1 \mathrm{a}} \quad \mathrm{SA}_{1}$-OM1-Aux-see-Fv

'Nchidzi can see him/her. (OM = 3rd person singular, class 1$)$ 


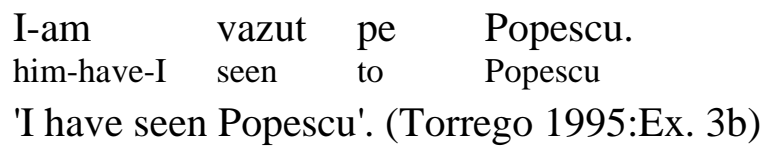

In the Romanian example (9), the clitic 'I' (him) attaches to the auxiliary 'am' (have).

\subsection{Only one OM per clause}

The OM also behaves like agreement morphology in that only one OM occurs per clause even though it is possible to have more than one internal object in the language. Consider the following example:

$\begin{array}{llll}\text { Nchídzí } & \text { wá-ka-bík-íl-á } & \text { mmé } & \text { nyá:ma. } \\ \text { Nchidzi }_{1 a} & \text { SA }_{1} \text {-PST-cook-APPL-FV } & \text { mother }_{2} & \text { meat }\end{array}$

(10b) ?Nchídzí wá- ka-1́-bá-bík-íl-á. Nchidzi $_{1 \mathrm{a}} \quad \mathrm{SA}_{1}$-PST- $\mathrm{OM}_{9}-\mathrm{OM}_{2}$-cook-APPL-FV

'Nchidzi cooked meat for my mother'. (N.B The sentence remains questionable even if we were to reverse the order of the OMs)

Although the occurrence of two OMS in the same clause is generally frowned at by speakers, there are some constructions where speakers judgments of these are positive. Consider the following:

$$
\begin{aligned}
& \text { Nchídzí wá- ka-í-n-túmíl-íl-á. } \\
& \text { Nchidzi }_{1 \mathrm{a}} \quad \mathrm{SA}_{1} \text {-PST-OM9-OM} \text {-Send-APPL-FV } \\
& \text { 'Nchidzi sent it to him/her' }
\end{aligned}
$$

In languages that have pronominal clitics such as Spanish, both the direct and indirect object can cliticize in the same clause as evident in Spanish example (12).

'They introduced her to the professor'. (Torrego 1995: Ex. 17)

The fact that examples such as (11) are judged possible by some speakers weakens the argument for OMs as agreement in Ikalanga because although these structures are not commonly used in everyday conversation, it might not necessarily be due to the fact that they are ungrammatical.

\subsection{OM shares phi features with lexical NP}

Another argument that could be used in favor of the agreement analysis is that the OM, like other pronominals shares grammatical features with the NP that it is anaphorically linked with: that is person, gender and number. For example, in (13b) the OM is $m$ - consonant with the grammatical features of noun class 1, that is third person singular human. Similarly the OM in example (13d) takes the grammatical features of class 7 which are third person singular non-human. Notice that 
the SA, which I analyze as agreement morphology also takes these same features. Be that as it may, notice that the subject marker $w a$ - and the OM have distinct forms even though they both carry similar grammatical features namely $3^{\text {rd }}$ person singular noun class $1 ; u$ ( $u-a$ in past tense) for subject agreement and $m$ - for object markers. Thus, the fact that they have distinctive forms is suggestive of the fact that they are different phenomena.

(13a) Nchídzí wá- ka - bón-á mbísá:na.

Nchidzi $i_{1 \mathrm{a}} \quad \mathrm{SA}_{1}$-PST- see-FV boy

Nchidzi saw a boy.

$\begin{array}{lll}\text { Nchídzí } & \text { wá ka m-bó:n-a } & \text { mbísána. } \\ \text { Nchidzi }_{1 a} & \text { SA }_{1} \text {-PST- OM- OMee-FV } & \text { boy }_{1}\end{array}$

'Nchidzi saw him, the boy'. (OM = 3rd person singular, class 1$)$

(13c) Nchídzí wá - ka - bón-á chíbúlú:lu

Nchidzi $_{1 \mathrm{a}} \quad \mathrm{SA}_{1}$-PST- see-FV $\quad$ lizard $_{7}$

'Nchidzi saw a lizard'.

(13d) Nchídzí wá - ka- chí-bó:n-á chíbúlúlu

Nchidzi $_{1 \mathrm{a}} \quad \mathrm{SA}_{1}-\mathrm{PST}-\mathrm{OM}_{7}$ see-FV $\quad$ lizard $_{7}$

'Nchidzi saw it, the lizard'. (OM=3rd person singular, class 7)

One of the features used to argue for OM as agreement morphology in the literature is its inability to reference the theme NP (Kramer, Baker 2010). The explanation given for this restriction is the locality condition of agreement relations; that is, the goal argument is the one that can agree with the OM because they are in the same domain. In Ikalanga however, both the goal and the theme NP can cliticize to the verb. Consider the examples below:

(14a) Nchídzí wá ka-kér-él-á $\quad$ Néo bá:na.

Nchidzi la $\mathrm{SA}_{1}$-PST-cut hair-APPL-FV $\mathrm{NeO}_{1} \quad$ children $_{2}$

'Nchidzi cut the children's hair on behalf of Neo'.

(14b) Nchídzí wá ka-ba-kér-él-á Né:o, bá:na.

Nchidzi $_{1 \mathrm{a}} \quad \mathrm{SA}_{1}$-PST- $\mathrm{OM}_{2}$-cut hair-APPL-FV $\quad \mathrm{NeO}_{1} \quad$ children

'Nchidzi cut it, the children's hair, on behalf of Neo'.

(14c) Nchídzí wá ka-n-kér-él-á bá:na Né:o

Nchidzi $_{1 \mathrm{a}} \quad \mathrm{SA}_{1}$-PST- $\mathrm{OM}_{1}$-cut hair-APPL-FV $\quad$ children $_{2} \quad \mathrm{Neo}_{1}$

'Nchidzi cut the children's hair on behalf of her, Neo.

The agreement analysis predicts that the highest argument of the two internal arguments will always be the one that takes an OM. However, in Ikalanga both internal arguments of the verb are allowed to cliticize to the verb; the theme argument as shown in (14b) and the goal argument as shown in (14c). This further weakens the agreement analysis because according to the Agree architecture outlined above, there should be no intervening NP with matching features between the probe, $v$ and the goal, which in this case is the NP ngwana 'child'. Thus the agreement analysis 
predicts that such an example should be ungrammatical, and it is not. Therefore, although there is evidence that the OM might be agreement morphology, such evidence is not very compelling. In the next section I present arguments in favor of OMs as pronominal clitics.

\section{Object Markers as Pronominal Clitics}

There is ample evidence in favor of analyzing OMs as pronominal clitics. Such evidence is morpho-syntactic, syntactic, and semantic in nature. I begin by presenting the morphosyntactic evidence before turning to the syntactic and finally the semantic evidence.

\subsection{Morpho-syntactic evidence}

\section{Interaction with mood and negation}

It has been observed in the literature that while agreement morphology varies due to the interaction with phenomena such as modality and negation, OMs are invariant with these phenomena (Nevins 2010, Kramer, Mullen 1986). In this paper, I distinguish between the SA, which I analyze as agreement morphology and the OM, which is a pronominal. Consider the following examples:
(15a) Nchídzí ú- no - bón-á mbísá:na
Nchidzi $_{1 \mathrm{a}} \quad \mathrm{SA}_{1}$-PRS-see-FV boy
'Nchidzi sees a boy'.
(15b) Nchídzí a-á zo- bón-á mbísá:na
Nchidzi $_{1 a} \quad$ NEG-SA 1 -PST- see-FV boy
'Nchidzi did not see a boy'.
Nchidzi $_{1 a} \quad$ COND.-SA 1 -comes Neo SA -FUT-run away
'If Nchidzi comes, Neo will run away'.
(15c) Nchídzí a-é zhá:, Néó ú-nootí:zha.

The subject agreement marker varies in form in the sentences above: (15a) is just a simple declarative in the present tense, and the form of the SA is $u-,(15 \mathrm{~b})$ is a negative form of the sentence and the SA is $a$ - and (15c) is a conditional sentence and the form of the SA is $e$-. Now consider the following examples involving OM.

(16a) Nchídzí ú - no - m-bó:n-á mbísána.

Nchidzi ${ }_{1 a} \quad$ SA $_{1}$-PRS-OM-see-FV boy

'Nchidzi sees the boy'. (Simple declarative)

(16b) Nchídzí a-á zo- m-bó:n-á mbísána.

Nchidzi $_{1 \mathrm{a}} \quad$ NEG-SA $_{1}$-PST-OM-see-FV boy

'Nchidzi did not see the boy'. (Negation) 


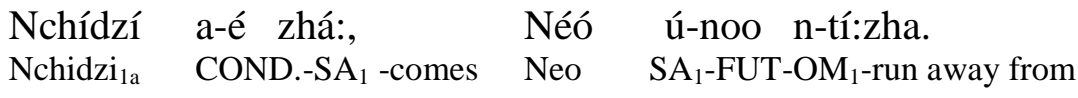

'If Nchidzi comes, Neo will run away from him'.(Conditional)

(16d) Ú-ngá n-thámíl-á tí:I?

$\mathrm{SA}_{1 \text {.sing.can }} \quad \mathrm{OM}_{1}$-make-FV tea

'Can he/she make tea for him/her. (Jussive)

(16e) ú-n--thámíl-é tí:I.

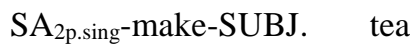

'Make tea for him. (Imperative)

In all the examples in (16), the OM is $m-/ n-;$ the variation in form is due to assimilation and not to any feature of the verb.

\section{Lack of obligatoriness}

Agreement morphology is usually obligatory in languages that have such morphology (Baker 2011, Corbett 2006). It has also been proposed in the literature (Woolford 2010) that there can only be one instance of agreement per clause ${ }^{4}$. With these proposals in mind, let us consider the examples below:

(17a) Nchídzí wá- ka- bón-á mbísá:na

Nchidzi ${ }_{1 a} \quad$ SA $_{1}$-PST see-FV boy

'Nchidzi saw a boy'.

$\begin{array}{lll}\text { *Nchídzí } & \text { ka - bón-á mbísá:na } \\ \text { Nchidzi }_{1 a} & \text { PST- see-FV } & \text { boy } \\ \text { 'Nchidzi saw a boy'. }\end{array}$

(18) a. John rides a bicycle.

b. * John ride a bicycle. (Standard English)

Subject agreement is obligatory in Ikalanga finite sentences as it is in other Bantu languages (see Mchombo 2004, 2001, Deen 2006, Letsholo 2004, 2007, Bresnan \& Mchombo 1987, Riedel 2009, Seidl \& Dimitriadis 1997). Therefore leaving it out of a sentence results in an ungrammatical sentence as attested in the Ikalanga example (17b) and the English example (18b). Notice however, that the OM is not obligatory in Ikalanga sentences: A sentence with a lexical object NP is grammatical without the OM. Consider the examples in (19).

(19a) Nchídzí wá- ka- -bón-á mbísá:na.

Nchidzi $_{1 \mathrm{a}} \quad \mathrm{SA}_{1}$-PST- see-FV boy

'Nchidzi saw a boy'.

${ }^{4}$ Notice though that if this proposal is correct, in all languages that have subject agreement, all OMs will have to be analyzed as pronominals regardless of the characteristics that they display. 
(19b) Nchídzí wá- ka- m- bó:n-a, mbísána.

Nchidzi $i_{1 a} \quad$ SA $_{1}$-PST- OM-see-FV boy

'Nchidzi saw him, the boy'.

(19c) Nchídzí wá - ka- m- bó:n-a.

Nchidzi $_{1 \mathrm{a}} \quad \mathrm{SA}_{1}$-PST-OM-see-FV

'Nchidzi saw him/her'. ( i.e. a specific boy)

(19a) without the OM is grammatical while in (19b) the OM is in anaphoric agreement with the NP mbisana 'boy'.Thus, OM lacks the obligatoriness that is associated with agreement morphology. This fact has also been observed for languages like Chichewa, Swahili and Amharic (Bresnan \& Mchombo 1987, Deen 2006, and Kramer respectively). One of the arguments posited in favor of the analysis of OMs as agreement in Amharic by Baker (2010) is that there are instances where the OM, just like agreement, is obligatory. One such instance involves experiencer arguments of non-agentive verbs such as 'worry', astonish', ' hurt e.t.c. While these kinds of verbs might trigger obligatory OMs in Amharic, this is not the case in Ikalanga. In fact, including the $\mathrm{OM}$ in these constructions results in ungrammaticality as observed in (20b and $21 \mathrm{~b}$ ) below.

(20a) Néó wá-ka- tshwények-a.

$\mathrm{Neo}_{1 \mathrm{a}} \quad \mathrm{SA}_{1}$-STAT. worried-FV

'Neo is worried'.

(20b) *Néó wá-ka-n-tshwények-a.

$\mathrm{NeO}_{1 \mathrm{a}} \quad \mathrm{SA}_{1}$-STAT-OM - worried-FV

'Neo is worried'

(21a) Néó wá-ka-gwádzík-a.

'Neo is hurt'

(21b) *Néó wá-ka-n-gwádzík-a.

$\mathrm{Neo}_{1 \mathrm{a}} \quad \mathrm{SA}_{1}$-STAT.-OM hurt-FV

'Neo is hurt'

Clearly this data cannot be used in any way to argue for obligatoriness of OMs in Ikalanga and so I safely conclude that in Ikalanga the OM is not obligatory except in instances where the lexical NP with which it co-refers has been omitted as in (19c).

\subsection{Syntactic evidence}

\section{Agreement and locality}

Agreement as understood in this paper, is a process in which two elements which are in a local configuration share morphological feature checking through a process of feature matching (Chomsky 1995, 2000). Consider the data below: 


$$
\begin{aligned}
& \text { Mbísáná íwó:yú, badálá bá-ká-búdzá shé kuti } \\
& \text { boy this old men } \mathrm{SA}_{2} \text {-PST-tell chief that } \\
& \text { a-bá-ngák-e bá-ká-n-khó:na } \\
& \text { Neg.-SA } 1 \text {-can-SBJV } \quad \text { SA }_{1} \text {-PST-OM }{ }_{1} \text {-manage }
\end{aligned}
$$

Notice that the OM is in the lowermost embedded clause while the NP with which it is coreferential, namely mbisana iwoyu 'this boy' is in the highest clause. The SA, an agreement marker, is in a local relation (Spec-head) with the NP (badala 'old men') with which it agrees. This suggests that agreement morphology and the OM in Ikalanga behave differently in terms of locality conditions, a fact which we can only account for if we acknowledge that the OM is anaphoric and therefore is not bound by the same locality conditions as agreement. It is indeed conceivable that there is a null object pro in the lower clause which would then be in a local relation with the OM similar to the subject pro in the same clause. While this is a plausible analysis, the evidence against the agreement analysis is nevertheless still compelling.

\section{Backward pronominalization}

Kramer observes that although backward pronominalization between subjects and objects in Amharic is almost ungrammatical, pronominalizing the object improves the grammaticality of a sentence in Amharic. The fact that such a sentence is grammatical means that the subject binds the OM. If the OM can be bound by the subject, this means that it is a pronominal and not an agreement marker since only arguments can be bound. The facts described for Amharic hold true in Ikalanga. Consider the data below:

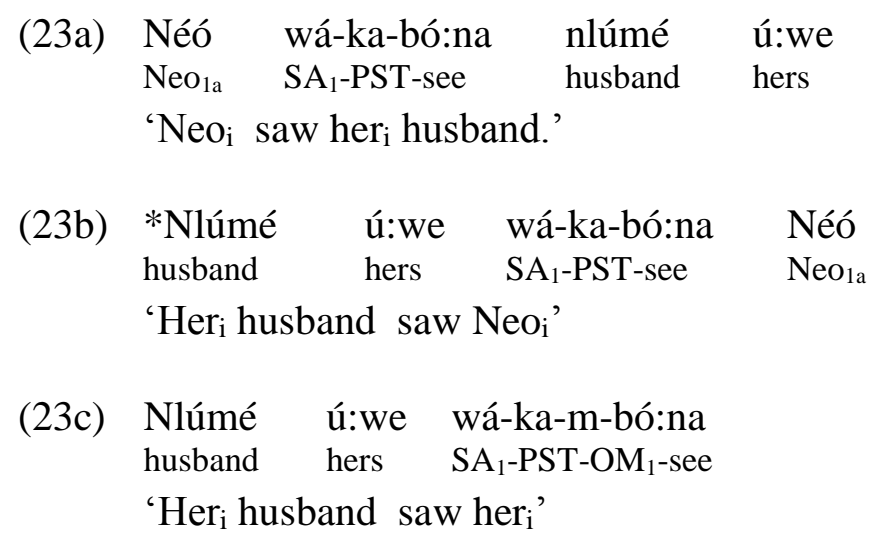

In example (23a), the subject binds the object NP and there is no problem there. In (23b) however, the subject NP cannot bind the NP Néó since this is an R-expression and it has to be free everywhere. We can however explain the grammaticality of $(23 \mathrm{c})$ if we assume that the OM $m$ - is a pronominal and as such can be bound by the R-expression nlume uwe 'her husband'.

\section{The status of the lexical NP in sentences with OM}

It has also been argued in the literature that an object marker that functions as agreement morphology co-occurs with the NP it refers to in the same phrase but that if the OM is a pronominal 
clitic then the NP with which it co-refers is dislocated (see Bresnan \& Mchombo, 1987). I provide evidence in the sub-section below that the NP with which the OM co-refers in Ikalanga is dislocated and that therefore the Ikalanga $\mathrm{OM}$ is a pronominal clitic and not agreement morphology. The evidence I provide in favor of the claim that the OM in Ikalanga is a pronominal clitic involves: a) the tonal patterns of the verb, b) word order facts in transitives, ditransitives and adverb placement and, c) lack of co-occurrence of OMs and question phrases.

\section{Tone}

Mathangwane (1999: 189) observes that Ikalanga does not have distinctive vowel lengthening but that nonetheless the language has a penultimate vowel lengthening rule which applies at the right edge of a phrase. A similar phenomena is observed for Chichewa by Bresnan \& Mchombo (henceforth B\&M) (1987: 749) who note that in phrase-final position, tonal changes are correlated with lengthening of the penultimate syllable. B\&M go on to propose that if the object marker and the lexical object NP are present in Chichewa then the object NP is not an argument of the verb but an adjunct. One piece of evidence they give in support of this idea is the effect of the presence of the lexical NP on the tone of the verb. According to these authors, the tone on the final vowel $e$ of the subjunctive verb is low if the verb is the final element of the verb phrase as in Chichewa ex. (24) in which the subject NP ana anga 'my children' is postposed. Notice that in the Ikalanga example (25), the subjunctive verb is in phrase final position, and there is lengthening of the penultimate syllable of the subjunctive verb bike 'cook'. In addition, the tone on the final vowel of this verb is low, just as in the Chichewa example.

$\begin{array}{lllll}\text { Ndikufúná } & \text { kutí } & \text { [a-pitirǐ:z-e] } & \text { aná } & \text { ánga. } \\ \text { I-want } & \text { that } & \text { SM-continue-SBJV } & \text { children } & \text { mine }\end{array}$

'I want my children to continue with the lesson'. (B\&M 1987: ex: 19)

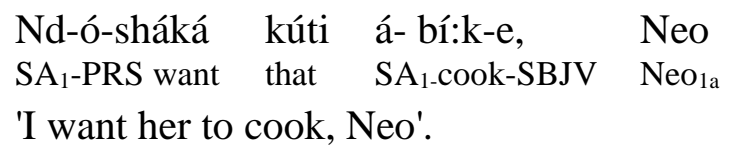

If however, a non-postposed object NP follows the subjunctive verb, two things happen: the low tone on the final vowel of the verb changes to a high tone and there is lengthening of the penultimate syllable of the item that is on the right-most edge of the verb phrase (ex. (26). These same changes are observed in Ikalanga example (27). In this example, the lexical NP nyama 'meat' is not postposed and the final vowel of the verb bike 'cook' is high while the penultimate vowel of the syllable nyama 'meat' is lengthened.

$\begin{array}{llllll}\text { (26) Ndi-kufúná } & \begin{array}{l}\text { kutí aná } \\ \text { I-want }\end{array} & \begin{array}{l}\text { ánga } \\ \text { that }\end{array} & \text { [a-pitiriz-é } & \text { phúnzi:ro } \\ \text { children } & \text { my } & \text { SM-continue-SBJV lesson }\end{array}$

'I want my children to continue with the lesson'.(B\&M 1987: ex: 17)

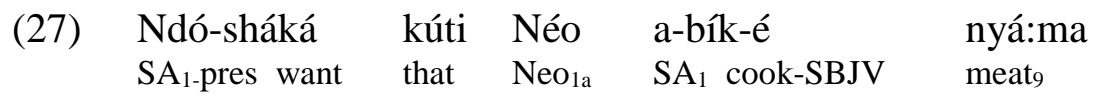

'I want Neo to cook meat'. 
If on the other hand both the object marker and the lexical object NP co-occur in a sentence, then the final vowel of the subjunctive verb is low, suggesting that the verb is at the right edge of the VP and that the lexical object NP is outside the VP. In Ikalanga example (28) the vowel lengthening falls on the penultimate syllable of the verb, $b i$; and the tone on the final vowel of the subjunctive verb is low, marking the edge of the VP. The object marker $i$ - co-occurs with the lexical object NP nyama 'meat'. Based on this (and other facts) B\&M conclude that the lexical NP in sentences in which the object marker co-occurs with the lexical object NP is an adjunct rather than an argument of the verb since it occurs outside of the verb phrase boundary. The Ikalanga data discussed so far are consistent with B\&M's conclusions, in other words, the verb phrase boundary in say, example (28) is indicated by the vowel lengthening of the verb bi:k-e as well as the low tone on the final vowel of this verb since this is a declarative. This means that anything that occurs beyond the verb phrase boundary is dislocated material.

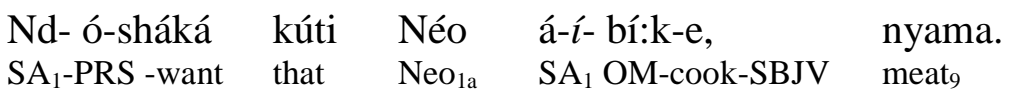

'I want Neo to cook it, the meat'.

\section{Word order}

In this sub-section, I discuss word order facts relating to adverb placement as well as word order in transitive and ditransitive sentences in the quest to provide evidence that NPs that co-occur with OMs are dislocated in Ikalanga. First, the adverb test.

\section{The adverb test}

Consider the data below:

(29a) Néó wá- ka- bík-á nyama madé:kwe.

Neo1a SA 1 -PST- cook-FV meat9 yesterday

'Neo cooked the meat yesterday'.

(29b) *Néó wá- ka- bík-á madékwe nyama $\mathrm{Neo}_{1 \mathrm{a}} \quad \mathrm{SA}_{1}$-PST- cook-FV yesterday meat 9

'Neo cooked the meat yesterday'.

(29c) Néó wá- ka- í-bík-á madé:kwe, nyama $\mathrm{Neo}_{1 \mathrm{a}} \quad \mathrm{SA}_{1}-\mathrm{PST}-\mathrm{OM}-\mathrm{cook}-\mathrm{FV}$ yesterday meat9

'Neo cooked it yesterday, the meat'.

In (29a), the edge of the VP is marked by the temporal adverb madekwe and thus we assume that the object NP nyama 'meat' forms part of VP. (29b) is ungrammatical because the object NP is outside the domain of VP and therefore the theme theta role of the verb bika 'cook' has not been assigned. (29c) with the object marker is grammatical providing further evidence for the argument proposed in B\&M that when the object marker is present, the lexical NP is an adjunct of the verb. In fact, (29c) provides evidence that the object NP is outside VP since the vowel lengthening falls on the penultimate syllable of the adverb madekwe 'yesterday' which marks the edge of VP. (29c) 
attests to the point made in Riedel (2009) that in terms of word order, right dislocated elements follow temporal adverbials cross linguistically. Thus the adverb test above provides evidence that if the OM is present, then the lexical NP is not in the same phrase (VP) as the OM in this language. This corroborates the point made above that dislocated lexical NPs do not occur in the same phrase as the OMs with which they co-refer if the OM is pronominal.

\section{Word order in transitives}

Languages that display flexibility in word order have been referred to in the literature as discourse configurational (Kiss 1995, Mchombo 2006). It is also assumed that these kinds of languages display flexibility because they use topic and focus strategies which result in placement of NPs in different positions. Ikalanga, at least to some degree, can be argued to be discourse configurational as it allows flexibility of word order in sentences that have an OM. Consider the examples below:

$\begin{array}{lll}\text { (30a) Néó } & \text { wá-ka-bíká } & \text { nyá:ma } \\ \mathrm{Neo}_{1 \mathrm{a}} & \text { SA-PST-cook } & \text { meat }_{9}\end{array}$

'Neo cooked meat'. $\quad$ (SVO)

(30b) Néó wá-ka-í-bí:ka nyáma.

'Neo cooked it, the meat'. $\quad$ (SVO)

(30c) Nyáma, Néó wá-ka-*(î)-bí:ka.

Meat ${ }_{9} \quad \mathrm{Neo}_{1 \mathrm{a}} \quad \mathrm{SA}_{1}$-PST-OM9-cook

'The meat, Neo cooked it'. $\quad$ (OVS)

(30d) Néó nyáma wá-ka-*(1)-bí:ka

$\mathrm{NeO}_{1 \mathrm{a}}$ meat SA $-\mathrm{PST}-\mathrm{OM}-\mathrm{cook}$

'Neo, the meat, she cooked it'. (OSV)

(30e) wá-ka-*(î)-bí:ka Néó nyáma

$\mathrm{SA}_{1}-\mathrm{PST}-\mathrm{OM}_{9}$-cook $\mathrm{Neo}_{1 \mathrm{a}} \quad$ meat $_{9}$

'She cooked it, Neo, the meat'. (VSO)

Without the OM, examples (30c-30e) are ungrammatical. This suggests that the lexical object NPs are topics in these sentences and that the theme theta role has not been assigned if the OM is left out in these examples hence the derivation crashes. In terms of the analysis proposed above, we can explain the ungrammaticality of $(30 \mathrm{c}-30 \mathrm{e})$ by saying that the EPP feature of $v$ has not been checked since the big DP containing the OM DP/D is not there to check this feature.

\section{Word order in ditransitives}

The canonical word order in ditransitive sentences in Ikalanga is such that the indirect (applied) object precedes the direct object. This is illustrated in (31a). 
$\begin{array}{llll}\text { (31a) Nchídzí } & \text { wá-ka túmíl-íl-á } & \text { Ludó } & \text { líkwá:lo. } \\ \text { Nchidzi }_{1 \mathrm{a}} & \text { SA }_{1} \text {-PST-send-APPL.-FV } & \text { Ludo }_{1 \mathrm{a}} & \text { letter }_{11}\end{array}$

'Nchidzi sent Ludo a letter'.

(31b) *Nchídzí wá-ka túmíl-íl-á líkwáló Lu:do Nchidzi $_{1 \mathrm{a}} \quad \mathrm{SA}_{1}$-PST- $\quad$ send-appl.-FV $\quad$ letter $_{11} \quad$ Ludo $_{1 \mathrm{a}}$

'Nchidzi sent Ludo a letter'.

$\begin{array}{lllll}\text { *Nchídzí } & \text { wá-ka } & \text { n-túmíl-íl-á } & \text { líkwáló, } & \text { Lu:do } \\ \text { Nchidzi }_{1 \mathrm{a}} & \mathrm{SA}_{1}-\mathrm{PST}-\mathrm{OM}_{1}- & \text { send-appl.-FV } & \text { letter }_{11} & \text { Ludo }_{1 \mathrm{a}} \\ \text { 'Nchidzi sent him/her a letter, Ludo'. } & \end{array}$

$\begin{array}{lllll}\text { Nchídzi } & \text { wá-ka- } & \text { gú-túmíl-1́l-á } & \text { Lu:do, } & \text { líkwá:ló } \\ \text { Nchidzi }_{1 a} & \text { SA }_{1} \text {-PST } & \text { OM }_{11} \text { - send-APPL.-FV } & \text { Ludo }_{1 a} & \text { letter }\end{array}$

'Nchidzi sent it to Ludo, the letter'.

(31e) ?Nchídzí wá-ka- gú-n-túmíl-íl-á, Lu:do, líkwá:ló Nchidzi $_{1 \mathrm{a}} \quad \mathrm{SA}_{1}$-PST $\quad \mathrm{OM}_{11}$ - $\mathrm{OM}_{1}$ - send-APPL.-FV $\quad$ Ludo $_{1 \mathrm{a}} \quad$ letter $_{11}$

'Nchidzi sent it to her, Ludo, the letter'.

$\begin{array}{lllll}\text { Nchídzí } & \text { wá-ka- } & \text { gú-túmíl-íl-á } & \text { líkwá:ló } & \text { Lu:do } \\ \text { Nchidzi }_{1 \mathrm{a}} & \mathrm{SA}_{1} \text {-PST } & \text { OM }_{11} \text { - send-APPL.-FV } & \text { letter }_{11} & \text { Ludo }_{1 \mathrm{a}}\end{array}$

'Nchidzi sent it to Ludo, the letter'.

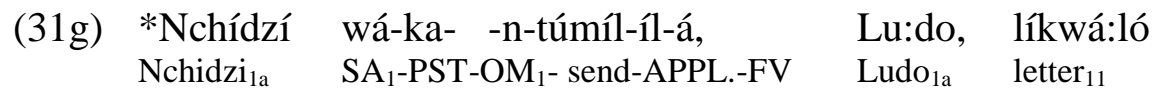

'Nchidzi sent him/ her a letter', Ludo.

Notice that (31b) in which the direct object precedes the applied object, the sentence is ungrammatical. In (31c), the direct object comes before the applied object because the lexical applied object NP Ludo is not VP internal. Rather, what is VP internal is the OM. Notice the lengthening of the penultimate vowel in the NP likwalo 'letter' signalling a VP boundary. In essence, the applied object argument of the verb namely the OM still precedes the direct object. (31d) is also grammatical with the direct object displaced. (31e) is ungrammatical because it is unusual for two OMs to occur on the same verb. The crucial examples from these data are (31f) and (31g). The ungrammaticality of these two sentences attests to two facts: a) the OM is not an agreement marker in Ikalanga: if it were, there would be no reason why $(31 \mathrm{~g})$ would be ungrammatical because the word order of the two object NPs is what we expect to see in Ikalanga, namely applied object followed by the direct object. b) the two lexical NPs in (31f \& $31 \mathrm{~g}$ ) are VP external and therefore there is a theta criterion violation since in each of the two sentences there is a theta role that goes undischarged.

\section{Word order in embedded sentences}

In (32a), the lexical NP mbisana iwoyu 'this boy' is right dislocated while in (32b) both the subject NP badala 'old men' and the lexical object NP are left dislocated. 
(32a)

\begin{tabular}{|c|c|c|c|c|}
\hline $\begin{array}{l}\text { Badálá } \\
\text { old men }{ }_{2}\end{array}$ & $\begin{array}{l}\text { bá-ká-búdz-á } \\
\text { SA2-PST-tell-FV }\end{array}$ & $\begin{array}{l}\text { shé } \\
\text { chief }\end{array}$ & $\begin{array}{l}\text { kuti } \\
\text { that }\end{array}$ & $\begin{array}{l}\text { a-bá-ngák-e } \\
\text { Neg.-SA } 1 \text {-can-SBJV }\end{array}$ \\
\hline & $\begin{array}{ll}\text { ha, } & \text { mbís } \\
\text { manage } & \text { boy }_{1}\end{array}$ & & & \\
\hline
\end{tabular}

(32b)

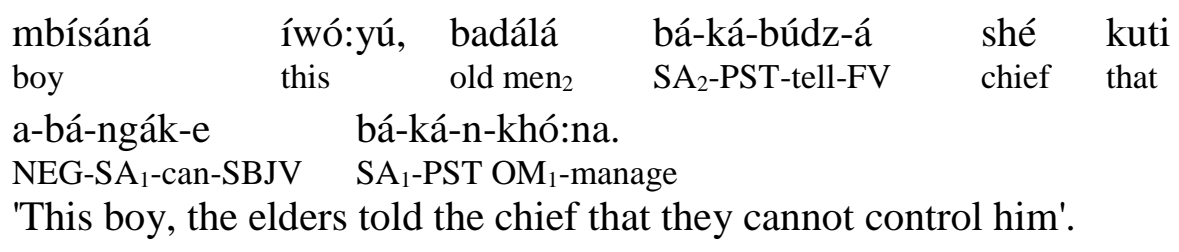

In (32a), there is an intonation break before the extraposed NP mbísáná íwóyú 'this boy', signalling the edge of VP. In addition, consonant with the arguments raised in section 5.2., there is vowel lengthening of the pen-ultimate syllable of the verb khona 'the one'and this marks the VP boundary in this sentence. Similarly, in (32b) there is an intonation break after the topicalized NP mbísáná iwóyú 'this boy' and there is lengthening of the pen-ultimate vowel of the verb khona 'the one' which marks a phrase boundary. If these lexical NPs are not in the same phrase as the OM, that suggests that the $\mathrm{OM}$ is a pronominal and not an agreement marker.

\section{Question constructions}

Ikalanga has two strategies for constructing WH questions (see Letsholo, 2007 for a detailed discussion of WH constructions in Ikalanga):

a) in-situ

$\begin{array}{llll}\text { (33a) Ludó } & \text { wá-ka-téng-él-á } & \text { ání bú:ka? } \\ \text { Ludo }_{1 a} & \text { SA } 1 \text {-PST-buy-APPL-FV } & \text { who book } \\ \text { 'Who did Ludo buy a book?' } & \text { (SA + V+ APPL+ Obj+ DO) }\end{array}$

b) Clefts

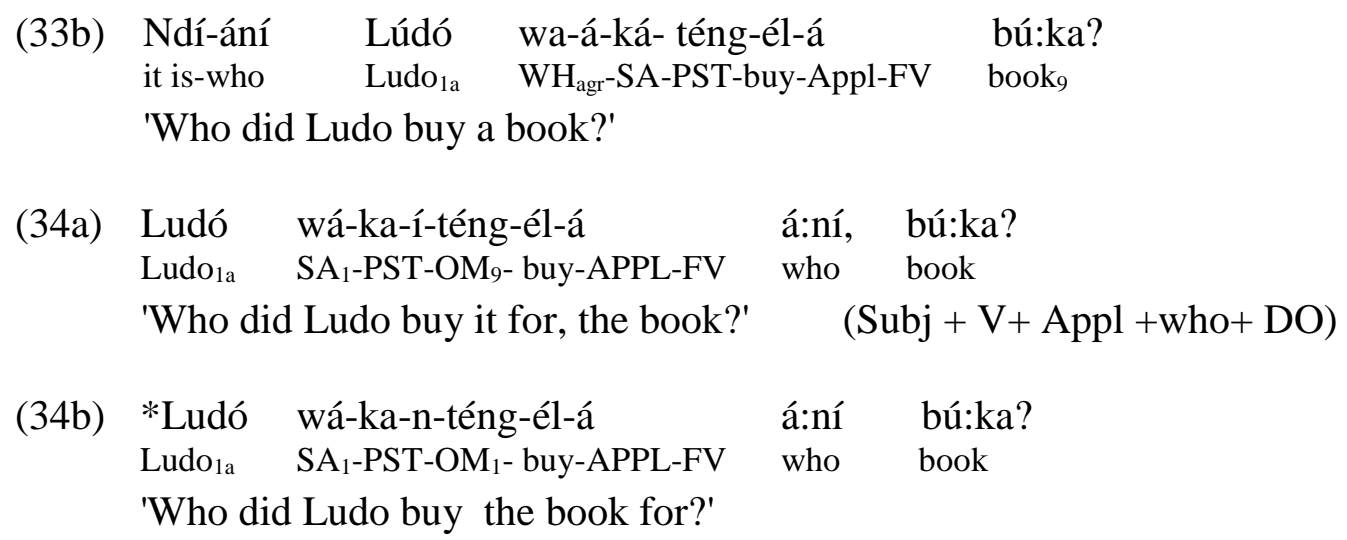


(34c)

*Ludó wá-ka-í-téng-él-á

Ludo $_{1 a} \quad$ SA $_{1}$-PST-OM9- buy-APPL-FV

'Who did Ludo buy it for, the book?' búka á:ní?

book who
*Ludó
wá-ka-n-téng-él-á
búka á:ní?

Ludo $_{1 \mathrm{a}} \quad$ SA $_{1}$-PST-OM - buy-APPL-FV

book who

'Who did Ludo buy a book?'
*Ndí-ání Lúdó
wa-á-ká-n- téng-él-á
bú:ka?
it is-who Ludo 1 a
$\mathrm{WH}_{\mathrm{agr}}-\mathrm{SA}_{1}$-PST-OM 21 -buy-Appl-FV
book9
'Who did Ludo buy a book?'

Example (34a) is grammatical: the OM is co-referential with the dislocated direct object NP buka' and not with the WH phrase $a n i$ 'who'. Notice the vowel lengthening on the penultimate vowel of the WH word ani 'who', indicating a phrase boundary. Example (34b) in which the WH phrase $a n i$ 'who' is co-referential with the OM is ungrammatical. There is more than one explanation why this sentence is ungrammatical. The first one is semantic and I leave it for discussion under section 5.3; the other is syntactic and has to do with theta role assignment. If, as already pointed out above, a DP which co-occurs with an OM is dislocated, then anything that linearly follows this displaced DP is itself displaced. Thus, if the DP ani is displaced, then it follows that the DP buka is also displaced. This means that the verb tengela is one argument short, a violation of the theta criterion. B\&M (1987)'s lexical functional grammar account for this kind of data is that WH phrases are focused constituents and therefore they cannot be topics at the same time (see Demuth \& Johnson 1990 for similar observations regarding Setawana).

The explanation above can be extended to example (34c), that is, this sentence is ungrammatical because the OM is co-referential with the NP buka 'book', which means that this NP is a topic and therefore outside VP. If this NP is outside VP, then consequently anything else that comes after it must be VP external, thus the WH word is also VP external. This means there is a theta criterion violation in this sentence because the applicative morpheme licences an extra theta role to the ones that the verb tenga 'buy' already has. If the NPs buka 'book' and ani 'who' are VP external, this means one theta role has not been assigned hence the ungrammaticality of this sentence. (34d) is a crucial example in this data in that its ungrammaticality provides solid evidence that a DP which co-occurs with an OM is dislocated in this language. In this example, both internal theta roles have been assigned: the goal theta role to the big DP containing the OM, and the theme theta role to buka. Why then is this sentence still ungrammatical? The ungrammaticality of this sentence can be explained if the WH word is an adjunct in this sentence, meaning it does not get a chance to move to the relevant specifier where it checks its question feature. (34e) is ungrammatical because both the $\mathrm{WH}$ word and the $\mathrm{OM}$ receive the same theta role (goal), a violation of the theta criterion. The evidence adduced so far regarding the syntactic status of lexical object DPs that co-occur with OMs is consistent with the properties of dislocated constituents outlined in Riedel (2009:68) which are as follows:

\section{A right dislocated phrase:}

- is a nominal phrase in clause final (or initial) position (following/preceding all of the core sentence components, 
- is co-indexed with a pronominal element inside the clause

- has an afterthought reading

- is phrased separately phonologically

\subsection{The semantic characteristics of the OM}

It is common knowledge in linguistics that agreement has no semantic bearing on a sentence (Lasnik 1999, Rezac 2010): all it does is to render a sentence as grammatical or ungrammatical without changing the meaning of a sentence in any given way. This is not what the OM does in Ikalanga. In this language (and other languages e.g. Chichewa and Amharic), the existence of the $\mathrm{OM}$ induces a definiteness/specificity effect on a DP in addition to adding emphasis. These facts can be explained if we assume that the big DP containing the OM shifts from its base position to spec VP as per the analysis proposed in this paper.

\section{Definiteness}

Like other Bantu languages, Ikalanga lacks determiners such as those found in languages like English (a, an, the) which are used to indicate definiteness (see Riedel 2009 for a similar observation regarding other Bantu languages).

Consider the example below:

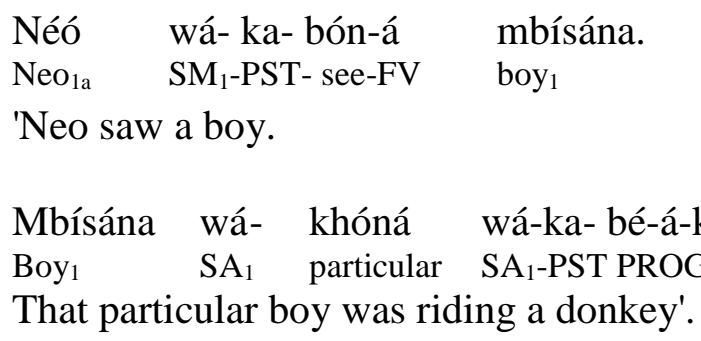

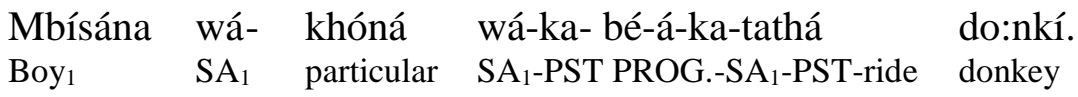

In the absence of determiners as mentioned above, like other Bantu languages (Riedel 2009), demonstratives and possessives can function like definite articles in Ikalanga. This is illustrated in (36). It is however possible to use the OM in these sentences where demonstratives and possessives have been used to function as definite articles. When this happens, the OM has two effects on the semantics of the sentence a) the DP with which the OM co-refers acquires definiteness and b) the DP becomes emphatic (37a\&b). The definite effect induced on DPs by OMs is also observed in other Bantu languages such as Zulu (Wald, 1979) and Kihung'an (Takizala, 1973) both cited in Morimoto (2002).

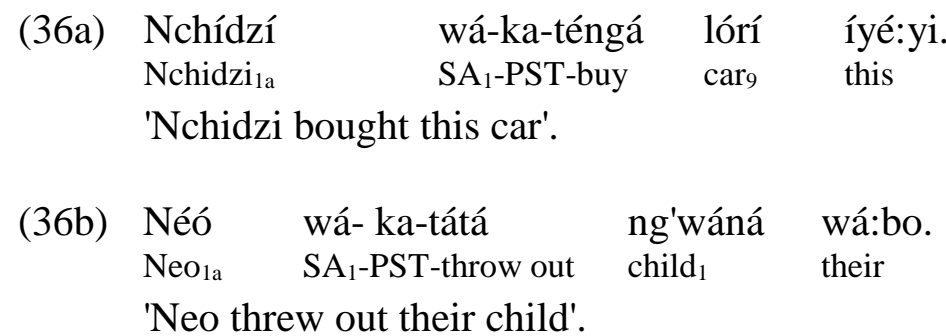


(37a) Nchídzí wá-ka-i-té:ngá lórí íyeyi

Nchidzi $_{1 \mathrm{a}} \quad \mathrm{SA}_{1}$-PST-OM9-buy car ${ }_{9}$ this

'Nchidzi did buy it, this car'.
Néó wá- ka-n-tá:ta
ng'wáná wábo.
$\mathrm{NeO}_{1 \mathrm{a}} \quad \mathrm{SA}_{1}-\mathrm{PST}-\mathrm{OM}_{1}$ - throw out
child $_{1}$ theirs

'Neo did throw him/her out, their child'.

If it is indeed the case that agreement has no semantic effect on a sentence, the fact that the OM has a definiteness effect as well as an emphatic bearing on the NP it co-refers with cannot be accounted for if we analyze OM as agreement.

Further evidence that OMs are not agreement morphology in Ikalanga comes from WH constructions. As already shown in section 5.2. WH phrases cannot co-refer with OMs. This is partly because WH phrases are indefinite DPS and following the discussion above about the association of OMs and definiteness and specificity, it is to be expected that the OM cannot cooccur with WH words in the same clause in this language. This prediction is borne out as example (34b) repeated as (38) below illustrates.

$$
\begin{aligned}
& \text { *Ludó wá-ka-n-téng-él-á áni bú:ka? } \\
& \text { Ludo }_{1 \mathrm{a}} \quad \mathrm{SA}_{1} \text {-PST-OM } 1 \text {-buy-APPL-FV who book } \\
& \text { 'Who did Ludo buy a book for?' } \quad \text { (SA + V+ APPL+ Obj+ DO) }
\end{aligned}
$$

\section{OM and specificity}

In terms of specificity, OM does play a role in distinguishing between specific and non-specific objects in Ikalanga. Riedel (2009) observes the same for Mainland Swahili while Kramer observes the same for Amharic. OM marked objects are always specific in Ikalanga. This fact is consonant with observations made in the literature, for example, Thráinsson (2001) who concludes that shifted objects must be interpreted specifically. In the analysis proposed in this paper, the DP containing the $\mathrm{OM}$ raises to $\mathrm{Spec} v \mathrm{P}$ where presumably its specificity feature is also checked.

$\begin{array}{lll}\text { (39a) Néó } & \text { wá- ka- bón-á mbísána. } \\ \mathrm{Neo}_{1 \mathrm{a}} & \mathrm{SA}_{1} \text {-PST-see-FV } & \text { boy }\end{array}$

'Neo saw a boy'.

(39b) Néó wá- ka-m bó:n-a mbísána.

$\mathrm{NeO}_{1 \mathrm{a}} \quad \mathrm{SA}_{1}$-PST-OM- see-FV boy

'Neo saw him, the boy'.

Thus the morpheme $m$ - brings about a meaning difference between (39a) and (39b). According to informants that I interviewed in Botswana, the NP mbisana 'boy' in (39a) has a non-specific meaning; it does not refer to any specific boy. On the other hand, the morpheme $m$ - in (39b) brings about specificity. Further evidence that OM brings specificity to an NP comes from the fact that non-specific objects cannot be object-marked. Consider the data below: 
(40a) A-kúná cha-ndá-ka-bó:na.

NEG-nothing $\quad \mathrm{NEG}_{\mathrm{agr}}-\mathrm{SA}_{1}$-PST-see

'I did not see anything'.

(40b) *A-kúná cha-ndá-ka-chi-bó:na.

NEG-nothing $\quad \mathrm{NEG}_{\mathrm{agr}}-\mathrm{SA}_{1}-\mathrm{PST}-\mathrm{OM}_{7}$ see

'I did not see anything'.

(41a)

A-kúná wa-bá-ka-sí:ya.

NEG.-nothing $\quad$ Agr $_{1}$-SA $A_{1}$-PST-leave

'They did not leave anyone behind'

(41b)
*A-kúná wa-bá-ka-n-sí:ya.
NEG.-nothing $\quad$ Agr $_{1}-\mathrm{SA}_{1}$-PST-OM - leave
'They did not leave anyone behind'

The (b) examples in $(40-41)$ are ungrammatical because the non-specific DP akuna 'nothing' corefers with the OMs in these sentences.

\section{Conclusion}

This paper makes contributions to the debate on the status of object markers in general but specifically in Bantu languages. The paper investigates the status of OMs in Ikalanga from both perspectives: that is, as agreement morphology and as pronominal clitics. In favor of the agreement analysis, the paper has argued that OMs attach only to the verbal stem and not to any other lexical category such as nouns or auxiliaries as do clitics in Indo-European languages. This behavior is consistent with agreement morphology. In addition, the paper has pointed out that in Ikalanga only one OM occurs per clause although there are instances where native speakers have judged some sentences with two OMs in a clause as possible in the language. Further, the paper has pointed out that OMs share grammatical features (person, gender and number) with the lexical NP with which they co-refer just like agreement morphology would.

The paper also presented arguments in favor of the pronominal analysis. Using morphosyntactic evidence, the paper argued that OMs in Ikalanga are not agreement markers but pronominal clitics similar to Italian/Romance clitics (Cardinaletti 2007). For example, the paper has shown that subject markers, which are agreement morphology, change form in response to changes in modality and negation while OMs, which are pronominal clitics maintain the same morphological form irrespective of changes in these syntactic phenomena. In addition, the paper also argued that agreement morphology is obligatory in order for a sentence to be rendered grammatical, e.g. subject markers in Ikalanga but OMs are not obligatory in this language. Further, the paper showed that agreement, for example between a subject and subject marker is a relation that is bound by locality conditions in this language, specifically spec-head relation. However, the locality condition of spec-head relation is not required for OMs since they can occur several clauses away from their antecedents.

In addition, the paper also argued that when a lexical object DP co-occurs with the OM, then it (the lexical object DP) is not an argument of the verb; rather, it is an adjunct. This has been used in the literature as evidence that the OM in such cases is a pronominal and not agreement. Evidence 
that the lexical DPs which co-refer with OMs in Ikalanga are adjuncts comes from phonological facts to do with vowel lengthening and tonal patterns which mark phrase boundaries in the language. More evidence for the adjuncthood of these lexical DPs comes from word order facts, and WH constructions. Furthermore, the paper showed that the occurrence of OMs in Ikalanga has a semantic import in the language, something that agreement morphology does not do. For example, OMs have a definiteness and specificity effect on lexical DPs with which they co-occur. When OMs co-occur with definite DPs such as those with demonstratives or possessives, their effect is to emphasize. Evidence that OMs are associated with specificity comes from the fact that they cannot co-occur with non-specific NPs such as 'anything' or 'no one' or WH phrases.

\section{References}

Baker, Mark. 2011. On the relationship of object agreement and accusative case: Evidence from Amharic. Linguistic Inquiry (available from website:

http://www.rci.rutgers.edu/ mabaker/Amharic-AgrO-Case-revised.pdf)

Bresnan, Joan. \& Sam Mchombo. 1987. 'Topic, pronoun and agreement in Chichewa'. Language $63.741-782$.

Cardinalleti, Anna. 2007. On different types of clitic clusters. University of Venice Working Papers in Linguistics 17. 27 - 76.

Chomsky, Noam. 2001. 'Derivation by phase'. Ken Hale: A Life in Language, ed. by Michael Kenstowicz, 1-52. Cambridge, Mass.: MIT Press.

----. 2000. Minimalist inquiries: The Framework. Step by Step: Essays on Minimalist Syntax in Honor of Howard Lasnik, ed. by Roger Martin, David Michaels \& Uriagereka. 89 - 155. Cambridge: MIT Press.

----. 1995. The Minimalist Program. Cambridge, Mass.: The MIT Press.

Corbett, Greville. 2006. Agreement. Cambridge: Cambridge University Press.

Deen, Kamil. 2006. Subject agreement in Nairobi Swahili. Selected Proccedings of the $35^{\text {th }}$ Annual Conference on African Linguistics. ed. by John Mugane, 225 - 233.Cascadilla Proceedings Project.

Demuth, Katherine. \& Mark Johnson. 1989. Interaction between discourse functions and agreement in Setawana. Journal of African Languages and Linguistics 11. 22 - 35.

Hyman, Larry, M. \& Duranti Allesandro. 1982. On the object relations in Bantu. Syntax and Semantics 15. $217-239$.

Jelinek, Eloise. (1984). Empty categories, case and configurationality. Natural Language and Linguistic Theory 2, $39-76$.

Keach, Camilla, N. 1995. Subject and object markers as agreement and pronoun incorporation in Swahili. Theoretical Approaches to African Linguistics ed. by Akinbiyi Akinlabi, 109 - 116. Trenton, New Jersey: Africa World Press.

Kiss, Katalina. 1995. Discourse Configurational Languages. New York: Oxford University Press.

Kramer, Ruth. Under review. Clitic doubling or object agreement: an Amharic investigation, available at

http://www9.georgetown.edu/faculty/rtk8/Clitic\%20Doubling\%20or\%20Object\%20Agreeme nt.pdf.

Labelle, Marie. 2007. Pronominal object markers in Bantu and Romance. The Bantu - Romance connection. A comparative investigation of verbal agreement DPs and information structure 
ed. by Cecile de Cat \& Katherine Demuth. Linguistiks Actuell/Linguistics Today, 83-109 John Benjamins.

Lasnik, Howard. 1999. Minimalist Analysis. Oxford: Blackwell.

Letsholo, Rose. 2004. Clausal and DP internal agreement in Ikalanga. Studies in African Linguistics 33/1.91 - 127.

-----. 2007. Who is where: Deriving right edge WH phrases in Ikalanga WH constructions. Lingua $117.986-1007$.

Marten, Lutz. \& Nancy Kula (ms.). Object marking and morphosyntactic variation in Bantu.

Mathangwane, Joyce. T. 1999. Ikalanga Phonetics and Phonology: A Synchronic and Diachronic Study. CSLI Publications: Stanford CA.

Matushansky, Ora. 2006. Head movement in linguistic theory. Linguistic Inquiry 37. 69 - 109.

Mchombo, Sam. 2001. Efects of Headmarking on constituent order in Chichewa. Proceedings of the LFG Conference, ed. by Miriam Butt \& Tracy Holloway King, CSLI Online Publications, http://cslpublications.stanford.edu/LFG

-----. 2002. Affixes, clitics and Bantu morphosyntax. Language Universals and Variation, ed. by Mengistu Amberber \& Peter Collins, 185-210. Westport CT: Prager.

-----. 2004. The Syntax of Chichewa. Cambridge: Cambridge University Press.

-----. 2006. Linear ordering constraints on split NPs in Chichewa. ZAS Papers in Linguistics 43. $143-160$.

Morimoto, Yokiko. 2002. Prominence mismatches and differential object marking in Bantu. Proceedings of the LFG02 Conference. 292 - 314. CLSI Publications.

Mullen, Dana. 1986. Issues in the morphology and phonology of Amharic: the lexical generation of pronominal clitics. Doctoral dissertation, University of Ottawa.

Nash, Jay. 1992. Aspects of Ruwund grammar. PhD dissertation, University of Illinois at Urbana - Champaign.

Rezac, Milan. 2010. $\varphi$ Agree versus $\varphi$ feature movement: evidence from floating quatifiers. Linguistic Inquiry 41. $496-508$.

Riedel, Kristina. 2009. The Syntax of Object Marking in Sambaa: A Comparative Bantu Perspective. LOT: The Netherlands.

Seidl, Amanda. \& Alexis. Dimitriadis. 1997. The discourse function of object marking in Swahili. CLS 33: The Main Session (1997). 373 - 389. Chicago Linguistics Society.

Takizala, Alexis. 1973. Focus and relativization: The case of Kihung'an. Syntax and Semantics 2. ed. by John P. Kimball, 123- 148. New York: New York Academic Press.

Thráinsson, Höskuldur. 2001. Object shift and scrambling. The Handbook of Syntactic Theory.ed. by Mark Baltin and Chris Collins, 148 - 202. Malden, M.A: Blackwell.

Torrego, Esther. 1995. On the nature of clitic doubling. Evolution and revolution in Linguistic Theory, ed. by Hector Campos, 399-418. Washington DC: Georgetown Press.

Wald, Benji. 1979. 'The development of the Swahili object marker: A study of the interaction of syntax and discourse'. Discourse and Syntax Vol.12 of Syntax and Semantics, ed.by Talmy Givón, 505-524. New York: Academic Press.

Woolford, Ellen. 2010. Active-stative agreement in Lakota. Ms. UMass Amherst. available at http://people.umass.edu/ellenw/. 
Author's Contact information:

Rose Letsholo

Department of English

University of Botswana

Private Bag 00703

Gaborone, Botswana

Fax: (267) 318-5098

Tel: (267) 355-4124

letsholor@mopipi.ub.bw 